\title{
Seeing is Believing? Evidence from Property Prices in Inundated Areas
}

\author{
Ajita Atreya \\ University of Georgia \\ 305 Conner Hall, Athens, GA 30602, USA \\ Phone: +1 706542 0843; Fax: +1 706 542-0739 \\ ajita@uga.edu \\ Susana Ferreira \\ University of Georgia \\ 313 Conner Hall, Athens, GA 30602, USA \\ Phone: +1 706542 0086; Fax: +1 706 542-0739 \\ sferreir@uga.edu
}

\begin{abstract}
We use spatial hedonic property models to estimate the changes in implicit flood risk premium following a large flood event. Previous studies have used flood hazard maps to proxy flood risk. In addition to knowing whether a property lies in the floodplain, we use a unique dataset with the actual inundation maps. We find that the price discount for properties in the inundated area is substantially larger than in comparable properties in the floodplain areas that did not get inundated. This suggests that, in addition to capturing an information effect, the larger discount in inundated properties reflects potential uninsurable flood damages, and supports a hypothesis that homeowners respond better to what they have visualized ("seeing is believing").
\end{abstract}

Key words: Flood Risk, Inundation, Spatial Hedonic Model, Difference-in-Differences. 


\section{Seeing is Believing? Evidence from Property Prices in Inundated Areas}

\section{Introduction}

A key element in hazard and disaster management is the understanding of how individuals perceive risk. Inadequate distinction between the three fundamental concepts of risk; subjective risk, objective risk and perceived risk, is a major difficulty towards managing flood risks (Slovic, 2000; Simonovic, 2011). Although probabilistic flood risk analysis deals effectively with objective risk arising from uncertainty, little attention is given to the assessment of subjective and perceived risks. Risk perception is the subjective assessment of the probability of a specific hazard happening and of the consequences of the negative outcome (Sjöberg, 2000). Individuals in a community may assess the risk of being flooded differently, because there are discrepancies in the probability of the flood hazard (e.g. as homes differ in terms of their location with respect to the floodplain), or in the flow of information about the probability of the flood hazard, for example because individuals are exposed to different scenarios of flooding (e.g. from being actually inundated to merely hearing about a flood event in the media). Intuitively, we would expect the flood risk perception of individuals to be more pronounced in those areas directly hit by a flood.

This paper considers the 1994 "flood of the century" in the city of Albany, Georgia, as a source of flood risk information to homeowners in Albany and determines the changes in implicit flood risk premium following the flood. In particular, we compare the price discount for properties in the actually inundated area to that for properties in the floodplain but outside the inundated area. In the United States, the Federal Emergency Management Agency (FEMA) uses a system of flood zones to convey information about the severity or type of flooding. For example, the 100-year flood zone, or Special Flood Hazard Area (SFHA) represents a 1\% chance 
of flooding per year, while the 500 -year flood zone represents a $0.2 \%$ chance per year. Previous studies have used FEMA designated flood hazard maps as a proxy for flood risk (Shilling et al., 1985; MacDonald et al., 1987; Speyrer and Ragas, 1991; Harrison et al., 2001; Beatley et al., 2002), and specific flood events as information shocks on perceived flood risk (Bin and Polasky, 2004; Carbone et al., 2006; Kousky, 2010).

Kousky finds that property prices in the 100-year floodplain did not change significantly but prices of properties in the 500-year floodplain declined by 2\% in St. Louis County, Missouri, following the 1993 flood in the Mississippi and Missouri rivers. Bin and Landry (2012) find that the risk premium for 100-year floodplain properties in Pitt County, North Carolina, increased in the wake of Hurricanes Fran and Floyd but that the effect was transitory. Similarly, Atreya et al. 2013 find a significant but short-lived discount for 100-year floodplain properties after the 1994 "flood of the century" in Dougherty county, Georgia. These results are consistent with the "availability heuristic" (Tversky and Kahneman, 1973), which is defined as a cognitive heuristic in which a decision maker relies upon knowledge that is readily available (e.g. what is recent or dramatic) rather than searching alternative information sources, when evaluating flood risks.

Previous papers, however, do not control for the actual inundation or the damages caused by flooding as these data are not readily available. In this paper, we limit our analysis to a smaller area in Dougherty county encompassing the city of Albany, for which damage data were available and are able to control for the damages caused by the 1994 flood. Moreover, in addition to FEMA hazard maps classifying floodplain areas, we use a map of the area that was not just at risk but inundated by the 1994 flood in Albany to tease out a "pure information effect" associated with being located in the floodplain from an "inundation effect". To the extent of our knowledge, 
this is the first paper that uses actual inundation maps to determine the effects of flood events on property prices.

We hypothesize that, following a large flood, the discount in properties in the inundated area will be large for two reasons: first, because homeowners in inundated areas are more likely to have experienced physical damages after the flood, and second, in terms of heightened flood risk perception, because people respond better to what they have experienced directly ("seeing is believing”). While, in principle, under conditions of perfect information and full insurance, flood insurance could cover cleaning and reconstruction costs, an increase in the discount of properties in the inundated area would reflect the incremental insurance costs and the residual risk for noninsurable losses, or the difference between the loss from flooding and the payment from the insurance company. Non-insurable losses include personal items with sentimental value, the risk of injury and death, the hassle of being displaced, damage to community infrastructure, etc.

We use a spatial hedonic property model in a difference-in-differences (DD) framework to determine the impact of the flood event on the estimated flood risk discount and to tease out the "inundation effect" from the "information effect" of a flood. Some studies have shown that flood risk is capitalized into property prices, and the price difference between houses inside and out of floodplain are often consistent with the discounted sum of future flood insurance payments (Harrison, Smersh, and Swhwartz 2001; Bin and Polasky 2004). Like Bin and Landry (2012) we do not find a significant discount for floodplain properties before the flood, but in the wake of the 1994 flooding event we find a significant, large discount of 20-34\% for floodplain properties. Consistent with previous studies (Atreya et. al 2013; Bin and Landry 2012) the flood discount vanishes over time. However, it is not possible to tell whether the estimated discount is the result of a pure information effect or an inundation effect. Many floodplain properties were in fact 
inundated and we suspect that a big part of the discount arises from the inundation and not from just being located in the floodplain.

To tease out a pure information effect, if any, from an inundation effect we divided our study area into four mutually exclusive groups: inundated and in the floodplain, inundated outside the floodplain, non-inundated and in the floodplain, and non-inundated outside the floodplain. If there is an information effect associated with being located in the floodplain, one might expect to see a discount for non-inundated floodplain properties as well, but our results suggest that this is not the case. We did not find any discount for the floodplain properties when we dropped the inundated properties from the model. The non inundated properties, including those in the floodplain, were not discounted significantly following the flood. Our results suggest that it is an inundation effect rather than a pure information effect that is capitalized into property prices. Despite federal requirement for flood insurance for floodplain properties, the lack of evidence of a pure information effect and of a persistent risk premium suggest limited awareness about flood hazards among buyers of floodplain properties.

\section{Study Area}

The city of Albany was founded in the early 1800s along the Flint River in Southwest Georgia. It comprises a total area of 55.8 square miles ( 55.5 square miles of land and 0.3 square miles of water, US Census Bureau, 2010). In 1994, a severe flood caused by tropical storm Alberto destroyed parts of downtown and south Albany, causing 15 deaths and displacing almost 22,000 people. Peak discharges greater than the 100-year flood discharge were recorded at all US Geological Survey (USGS) Flint River gauging stations (Stamey, 1996). At Albany, the Flint 
River peaked at a stage about $5 \mathrm{ft}$ higher than the $1925 \mathrm{flood}$, which was the previous maximum flood recorded at that gauging station.

Albany is one of the nearly 20,000 communities across the US and its territories voluntarily participating in the National Flood Insurance Program (NFIP). The NFIP makes federally backed flood insurance available to homeowners, renters, and business owners in participating communities, that in exchange adopt and enforce floodplain management ordinances to reduce future flood damage. In order to actuarially rate new constructions for flood insurance and create broad-based awareness of the flood hazards, FEMA maps 100-year and 500-year flood plains in participating communities. ${ }^{1}$ Homes and buildings in high risk flood areas, those with $1 \%$ or greater chance of flooding in any given year, and with mortgages from federally regulated or insured lenders are required to have flood insurance.

In addition to FEMA hazard maps, typically used in the literature to model flood risk, we use a map of the area that was actually inundated by the 1994 flood. The USGS along with partners at the National Weather Service (NWS), the U.S. Army Corps of Engineers (USACE), FEMA, state agencies, local agencies and universities, has developed a web-based tool for flood response and mitigation with a major goal of reducing vulnerability of people and areas most at risk from natural hazards. It provides digital geospatial flood-inundation maps that show flood water extent and depth on the land surface. USGS has modeled flow characteristics of flooding along a 4.8-mile reach of the Flint River in Albany, Georgia, using recent digital-elevationmodel data and the USGS finite-element surface-water modeling system for two-dimensional flow in the horizontal plane. Simulated inundated areas, in 1-foot (ft) increments, were created

\footnotetext{
${ }^{1} 100$-year and 500 -year floodplain refer to the flooding probability, $1 \%$ and $0.2 \%$ in a given year, respectively.
} 
by USGS for water-surface altitudes at the Flint River at Albany stream gage from 179.5-ft altitude to 192.5 -ft altitude. Figure 1 shows the study area and the inundated area for a water surface altitude of 192.5 feet at Flint River, which corresponds to the 1994 flood caused by tropical storm Alberto.

\section{Methods}

Following the standard hedonic approach (Rosen, 1974; Freeman, 2003), we model the price of a property, $P$, as a function of structural characteristics, $\mathbf{S}$ (e.g. number of rooms, size of the house), neighborhood and location characteristics, L (e.g. distance to river, distance to parks), and the location with respect to the inundated area (IND) in addition to the location in floodplain $(F P)$. We use a quasi-experimental Difference-In-Differences (DD) approach (Atreya et. al, 2013; Bin and Landry, 2012; Kousky, 2010) to measure the effect of a large flood event on flood prone property prices. The DD design allows us to isolate the effect attributable to the flood from other contemporaneous variables (e.g. macroeconomic shocks, changes in local housing or labor markets), since the control group experiences some or all of the contemporaneous influences that affect property values in the treatment group but offers lower flood risk. We estimated three different models.

\section{Model 1}

Following Bin and Landry (2012) and Atreya et al. (2013) the simplest model uses the FEMA designated floodplain maps to measure flood risk in the following specification:

$$
\begin{aligned}
& \ln \left(P_{i t}\right)=\beta_{0}+\lambda \sum_{j} w_{i j} \ln \left(P_{j t}\right)+\boldsymbol{\beta}_{1}^{\prime} \ln \mathbf{L}_{\mathbf{i}}+\boldsymbol{\beta}_{2}^{\prime} \mathbf{S}_{\mathrm{it}}+\boldsymbol{\beta}_{3}^{\prime} \mathbf{S}_{\mathrm{it}}^{2}+\beta_{4} F P_{i}+\beta_{5} \text { Flood }_{i t}+ \\
& +\beta_{6} F P_{i}^{*} \text { Flood }_{i t}+\beta_{7} f(\text { years })+\beta_{8} f(\text { years }) * F P_{i}+\beta_{9} \text { Damage }_{i}+\delta_{t}+\varepsilon_{i t}
\end{aligned}
$$


In the DD design, FP is a dummy equal to 1 if the property falls in the floodplain and zero otherwise, and the control group are properties outside the floodplain. The variable Flood is a dummy variable equal to one if the sale happened after the flood (July 1994). The interaction term between the Floodplain variable (FP) and Flood tells us how the 1994 flood might have affected the prices of properties in the floodplain sold after the 1994 flood.

To examine the persistence of the risk premium over time after the 1994 flood we used interaction terms between f(years) and the floodplain variable, where "years" is the number of years after the 1994 flood. Previous papers (Bin and Landry, 2012; Atreya et al., 2013) find this temporal decay effect to be important. In addition to using a linear time trend (f(years)=years), we explored an alternative, non-linear functional form, the natural logarithm, f(years)=ln(years).

With the variable Damage we seek to control for the physical damages to the properties affected by the flood. Unfortunately, we do not have information on flood damages (if any) at the structure level suffered by the properties in the inundated area, but we have information on two alternative indicators. First, we consider the average dollar losses from the 1994 flood at census block level, generated using HAZUS, a software developed by FEMA to estimate flood damages. $^{2}$ We controlled for damages in the 114 census blocks in the inundated study area. These census blocks are small, with just 12 houses on average. Second, assuming that the depth of the flood water acts as a proxy to the degree of structural damages to the properties in the inundated area, we extracted the flood depth in the inundated study area at a gauge height of 43 feet and an altitude of 192.5 feet corresponding to the 1994 flood using a raster map developed by USGS. Because inundation depth reflects both flood severity and the ground elevation of a building (Zhai and Fukuzono, 2003), we subtracted the land surface elevation from the model

\footnotetext{
2 The HAZUS generated data was provided by Paul P. Hearn, Chief, Research Station, Eastern Geographic Science Centre, U.S. Geological Survey, and Eastern Region (http://wim.usgs.gov/FIMI/FloodInundationMapper.html).
} 
elevation. We expect structural damages to be greater for properties located at higher flood depths, and thus, expect to find a higher price discount for those properties.

We performed a Box-Cox transformation of the dependent variable and after comparing the residual sum of squares we concluded that the natural log of price as the dependent variable was the best specification for our model. After testing several transformations of the independent variables, the location variables $\mathbf{L}$ were best fitted in their $\log$ form while the other attributes $\mathbf{S}$ were fitted best in their quadratic specification. Year fixed effects $\left(\delta_{t}\right)$ were included to capture yearly shocks that may affect all the properties. Subscripts $i$ and $t$ represent property and time respectively.

An important econometric issue in hedonic models concerns the potential spatial dependence of the observations. Neighboring properties are likely to share common unobserved location features, similar structural characteristics due to contemporaneous construction, neighborhood effects and other causes of spatial dependence. Ignoring the problem could result in inefficient or inconsistent parameter estimates (Anselin and Bera, 1998). To account for spatial dependence we use a spatially lagged and autoregressive disturbance model, frequently referred to as a SARAR model (Anselin and Florax, 1995). The model allows for spatial interactions in the dependent variable, the exogenous variables, and the disturbances. Spatial interactions in the dependent variable are modeled through a spatial lag structure that assumes an indirect effect based on proximity (i.e. the weighted average of other housing prices affects the price of each house). The error term incorporates spatial considerations through a spatially weighted error structure which assumes at least one omitted variable that varies spatially leading to measurement error. 
In equation (1) $\varepsilon_{i t}=\rho \sum_{j} m_{i j} \varepsilon_{j t}+u_{i t}$, and the disturbances $u_{i t}$ are assumed to be independent and identically distributed. $w_{i j}$ and $m_{i j}$ are the elements of $\mathrm{W}$ and $\mathrm{M}$, two $n \times n$ spatial weights matrices that are taken to be known and non-stochastic, and $\lambda$ and $\rho$ are the spatial autocorrelation parameter and spatial autoregressive coefficient, respectively. As in Fingleton (2008), Fingleton and Le Gallo (2008), Kissling and Carl (2008), and Kelejian and Prucha (2010) we assume $\mathrm{W}=\mathrm{M} .^{3}$ Concerning the spatial weights matrix, W, two frequently used specifications are contiguity matrix and inverse distance matrix. In our estimation, we used a contiguity matrix, where adjacent properties get a weight of one and zero otherwise. ${ }^{4}$

\section{Model 2}

In order to explore the inundation effect and to determine the changes in property prices in the inundated area after the 1994 flood, we used the USGS inundation map of the study area. In the specification below, the control group is composed of properties that are outside the inundated area:

$$
\begin{aligned}
& \ln \left(P_{i t}\right)=\beta_{0}+\lambda \sum_{j} w_{i j} \ln \left(P_{j t}\right)+\boldsymbol{\beta}_{1}^{\prime} \ln \mathbf{L}_{\mathbf{i}}+\boldsymbol{\beta}_{2}^{\prime} \mathbf{S}_{\mathbf{i t}}+\boldsymbol{\beta}_{3}^{\prime} \mathbf{S}_{\mathbf{i t}}^{2}+\beta_{4} I N D_{i}+\beta_{5} \text { Flood }_{i t}+ \\
& +\beta_{6} I D_{i} * \text { Flood }_{i t}+\beta_{7} f(\text { years })+\beta_{8} f(\text { years }) * I N D_{i}+\beta_{9} \text { Damage }_{i}+\delta_{t}+\varepsilon_{i t}
\end{aligned}
$$

The variable IND (inundation) is a dummy equal to 1 if the property was inundated by 1994 flood and 0 otherwise.

\footnotetext{
${ }^{3}$ According to Anselin and Bera, the SARAR model requires that either $\mathrm{W} \neq \mathrm{M}$ or the existence of one or more explanatory variables. The latter is true for our model.

${ }^{4}$ We did not use an Inverse Distance Weights matrix (IDW) because IDW requires the observations to be unique. Note that as the distance between a property and itself is zero, its inverse would be indeterminate, and we would lose half of our observations leading to a substantially smaller sample size.
} 


\section{Model 3}

We also divided the properties within the study area into four mutually exclusive groups: inundated and in the floodplain (IN_FP), inundated outside the floodplain (IN_OFP), noninundated and in the floodplain (NIN_FP) and non-inundated outside the floodplain (NIN_OFP). Model 3 explores the effect of the 1994 flood in these mutually exclusive groups using the properties outside both the floodplain and inundated areas, NIN_OFP, as the control group.

$$
\begin{aligned}
& \ln \left(P_{i t}\right)=\beta_{0}+\lambda \sum_{j} w_{i j} \ln \left(P_{j t}\right)+\boldsymbol{\beta}_{1}^{\prime} \ln \mathbf{L}_{\mathbf{i}}+\boldsymbol{\beta}_{2}^{\prime} \mathbf{S}_{\mathrm{it}}+\boldsymbol{\beta}_{3}^{\prime} \mathbf{S}_{\mathrm{it}}^{2}+\beta_{4} I N_{-} F P_{i}+\beta_{5} I N_{-} O F P_{i}+\beta_{6} N I N_{-} F P_{i}+ \\
& +\beta_{7} \text { Flood }_{i t}+\beta_{8} I N_{-} F P^{*} \text { Flood }_{i t}+\beta_{9} I N_{-} O F P_{i} * F \operatorname{Food}_{i t}+\beta_{10} N I N_{-} F P_{i}^{*} F_{l o o d}+\beta_{11} f(\text { years })+ \\
& +\beta_{12} f(\text { years }) * I N_{-} F P_{i}+\beta_{13} f(\text { years }) * I N_{-} O F P_{i}+\beta_{14} f(\text { years }) * N I N_{-} F P_{i}+\beta_{15} \text { Damage }_{i}+\delta_{t}+\varepsilon_{i t}
\end{aligned}
$$

Finally, regarding the estimation procedure for Models 1-3, the existence of spatial autocorrelation increases the possibility that the errors will not be distributed normally. ${ }^{5} \mathrm{~A}$ maximum likelihood estimation procedure requires strong distributional assumptions (Kelejian and Prucha, 1998). We employ an alternative generalized spatial two stage least squares (GS2SLS) estimator that is computationally simple, makes modest distributional assumptions and produces consistent estimates when the model contains both a spatially lagged dependent variable and a spatially autocorrelated error term (Arraiz, et al., 2010). ${ }^{6}$ The GS2SLS estimator

\footnotetext{
${ }^{5}$ The Jarque-Bera test for normality of the residuals suggested that the residuals are not normally distributed (Skewness $=0.16$ and Kurtosis $=4.49$ )

${ }^{6}$ We use the spreg gs2sls command in STATA 12.1 that implements Arraiz et al. (2010) and Drukker, Egger, and Prucha (2009) estimators and allows for both spatial lag and spatial error corrections. The SARAR estimators are produced in four steps: 1) Consistent estimates of $\boldsymbol{\beta}$ and $\lambda$ are obtained by instrumental-variables estimation. Following Kelejian and Prucha (1998) the valid instruments are the linearly independent columns of the exogenous variables $\mathrm{X}, \mathrm{WX}$, and $\mathrm{W}^{2} \mathrm{X}$, which is used as default by the program. 2) $\rho$ and the variance $\sigma^{2}$ are estimated by GMM using a sample constructed from functions of the residuals. The moment conditions explicitly allow for heteroskedastic innovations. 3) The estimates of $\rho$ and $\sigma^{2}$ are used to perform a spatial Cochrane-Orcutt transformation of the data and obtain more efficient estimates of $\boldsymbol{\beta}$ and $\lambda .4$ ) The efficient estimates of $\boldsymbol{\beta}$ and $\lambda$ are used to obtain an efficient GMM estimator of $\rho$.
} 
produces consistent estimates also when the disturbances are heteroskedastic, as is our case, ${ }^{7}$ while the ML estimator could produce inconsistent estimates in the presence of heteroskedasticity (Arraiz et al., 2010).

\section{Data}

We used four data sources to construct our dataset: Dougherty County’s Tax Assessor's Office for individual property sales of residential homes in the city of Albany; Georgia's Geographic Information System (GIS) clearinghouse for parcel level GIS data; USGS and FEMA for flood inundation and floodplain maps of Flint River at Albany, respectively; and USGS Flood Inundation Mapper to estimate potential losses from the 1994 flood at census block level. Each property is a single-family residence sold between 1985 and 2007.

Individual property sales data contain information on housing characteristics $\mathbf{S}$ such as number of bedrooms, number of bathrooms, heated square feet, presence of garage, in addition to sale date and sale price $P$. Property sale prices were adjusted to 2007 constant dollars, using the housing price index for Albany metropolitan area from the Office of Federal Housing Enterprise Oversight (OFHEO). ${ }^{8}$ The GIS database was utilized to determine the location attributes of the properties $\mathbf{L}$ such as proximity to rivers, railroad, major roads, and parks. Other neighborhood characteristics (median household income and percent of non-white residents) were determined at the block group level using 2000 census data. ${ }^{9}$ The floodplain map published as Q3 data by

\footnotetext{
${ }^{7}$ The Breush-Pagan/Cook Weisberg test for heteroskedaticity (chi square=48.90, p-value $=0.000$ ) rejected the null hypothesis of constant variance.

${ }^{8}$ We use the OFHEO index over other housing price indices such as the Case-Shiller index. While the OFHEO index is available for 363 Metropolitan Statistical Areas (MSAs) including Albany, GA, which is the focus of our study, the Case-Shiller index covers only 20 major MSAs which include Atlanta, but not our study area. Visual inspection of the OFHEO indices for Atlanta and Albany suggests that these are very different real estate markets subject to different demand conditions. The growth rate of Census population figures for the Atlanta MSA was 3.1\% per year between 1985 and 2010, but only 0.56\% for the Albany MSA.

${ }^{9}$ Block Groups generally contain between 600 and 3,000 people, with a typical size of 1,500 people.
} 
FEMA was used to determine if the parcel was within or outside the 100 -year floodplain. ${ }^{10}$ Simulated flood inundation for a water surface altitude of 192.5 feet at Albany's stream gauge corresponding to the 1994 flood was used to determine the inundated area. We confined our study area to the flood inundation study area at Flint River, Albany, prepared by USGS (Figure 1), which includes a little over 2,600 single-family residences.

In conjunction, the 100-year floodplain map and the inundation map define the four mutually exclusive groups employed in the estimation of Model 3: inundated and in the floodplain (IN_FP), inundated outside the floodplain (IN_OFP), non-inundated and in the floodplain (NIN_FP) and non-inundated outside the floodplain employed in Model3. Table 1 shows the number of properties in each group. Given the few number of observations in the NIN_FP category, we did not consider a separate set of variables for properties in 500-year floodplain, as there were only 183 properties in the 500-year floodplain. In addition, homeowners are not required to buy flood insurance if they are located in the 500-year floodplain and therefore might be unaware of the flood hazard associated with the location of their properties. However, we did try a broader definition of the floodplain variable by merging both the 100- and 500-year floodplain properties. This increased the number of observations in the NIN_FP category to 133. The results discussed in Section 5 were robust to this change.

Table 2 reports the summary statistics for all the variables considered in the analysis. The mean property price was 80,221 in 2007 constant dollars. The oldest property was built in 1883 . The average property had 0.26 acres. The maximum elevation was 216 meters and the minimum elevation 175 meters. Mean distance to the nearest River was 671 meters. Of all the sales

\footnotetext{
${ }^{10}$ As part of a countywide flood map modernization program, the state of Georgia in cooperation with FEMA published a new floodplain map for Dougherty County in 2009. In our analysis, we choose the 1996 map as the large flood event in our study occurred in 1994 and all of our sales transaction occurred before 2009.
} 
between 1985 and 2007, 23\% of the properties were in the 100-year floodplain and 29\% of the properties in the sample were inundated during the 1994 flood.

Economic theory does not provide definite guidance on the correct data range to be used in hedonic models, except that the contribution of the various characteristics to the value of the house should have been relatively stable over that time period (Palmquist, 2005). Our sample period (1985-2007) covers more than 10 years after the 1994 flood. This time period is long enough to capture the time trend in the flood risk discount following the 1994 flood, while excluding more recent, post-recession observations. In order to check the stability of the housing attributes during this time period, we performed a series of paired $t$-tests on the characteristics of the average property before and after the 1994 flood and we failed to reject the null of equal means for the two time periods for most of the attributes. ${ }^{11}$ Notably, the proportion of houses in the floodplain, and most of the structural variables, including important attributes such as lot size (acres) and the heated squared footage, are not significantly different across the two sub-samples.

\section{Results}

Table 3 reports the SARAR estimates of the DD models presented in Section 3 using a linear time trend $(f($ years $)=$ years $)$ and the average flood damage at the census block level as a proxy for flood damages.

In the first column of Table 3, we present the estimates of Model 1, which following previous studies simply estimates the effect of the flood on the prices of floodplain properties irrespective of whether the property was inundated or not. Flood risks, as measured by being located in the floodplain $(F P)$, are capitalized into property prices only after the flood. We do not

\footnotetext{
11 Results for these tests are available upon request.
} 
find a significant discount for floodplain properties before the 1994 flood. We find that properties in the floodplain were sold for $33 \%$ less than an equivalent property outside the floodplain immediately following the 1994 flood, which is equivalent to about $\$ 26,500$ when evaluated at the average price home. ${ }^{12}$ However, consistent with previous studies that find a temporal decay effect, we find that the large discount is short lived. Seven years after the flood it is not statistically different from zero.

In the second column, we estimated the effect of the 1994 flood on flood prone properties in the study area as determined by whether they fall in the inundated area or outside the inundated area (Model 2). We find that immediately after the flood, properties in the inundated area sold for 39\% less than equivalent properties outside the inundated area. Even controlling for flood damages using the census block average damage, this is a $16 \%$ larger discount than for floodplain properties in Model $1 .^{13}$ Again, we find that the discount for the properties in the inundated area diminished over time vanishing seven years after the flood.

To tease out the effect of being inundated from the informational effect of being in the floodplain, we estimated Model 3 wherein we divided the study area into four mutually exclusive groups. Compared to non-inundated properties outside the floodplain, we find that inundated floodplain properties (IN_FP) were discounted by $41 \%$ immediately after the flood. Similarly, we find a significant discount of $33 \%$ for the properties that were inundated but were located outside the floodplain (IN_OFP). Interestingly, the non-inundated properties were not discounted significantly even if they were located in the floodplain (NIN_FP). This suggests that it is in fact

\footnotetext{
${ }^{12}$ In a semilogarithmic equation such as (1), the marginal effect of the dummy $F P^{*} F$ lood in the first column is given by $(\exp (-0.395)-1) *(1 /(1-0.00557))=-0.33$. (Halvorsen and Palmquist, 1980). Note that, we also take into account the spatial multiplier $1 /(1$-lambda) when determining the marginal effect.

13 The 39\% discount is calculated as $(\exp (-0.496)-1) *(1 /(1-0.00557))=-0.39$.
} 
the inundation effect that is capitalized into property prices. We suspect that the significant discount found for floodplain properties in studies that do not control for whether the properties were inundated or not might be due to the inundation effect rather than an information effect associated with being located in the floodplain. Across all the specifications, we find that the price discount is temporary, decaying over time. The parameter estimates of the interaction term between the flood risk variables (FP, IND, IN_FP and IN_OFP and the years variable are always positive and statistically significant.

The significant spatial autocorrelation parameter $(\rho)$ and spatial autoregressive coefficient $(\lambda)$, towards the bottom of Table 3 suggest that for all the specifications there is, in fact, spatial dependence among the properties in our dataset in the expected direction: a positive adjacency effect. We expect a positive $\lambda$ since a higher sale price of neighboring properties should result in a higher average sale price, ceteris paribus. Conforming to intuition, $\lambda$ is significant at a 1 percent level and robustly estimated at $0.0055-0.0056$ across specifications, indicating that if the weighted average of neighboring houses' sale price increases by 1 percent, the sale price of an individual house increases by approximately 0.0055 percent. ${ }^{14}$ Regarding the interpretation of the regression coefficients, in the spatial lag model, marginal effects are calculated by multiplying the estimates times a spatial multiplier, 1/(1- $\lambda$ ) (Kim, Phipps, and Anselin, 2003). A larger $\lambda$ means a larger spatial dependence and thus, a larger spatial multiplier.

Regarding other controls, across all the specifications, the median household income by block group has an expected significant positive sign. Proximity to the railroad, parks and schools increases the property prices significantly as does the heated square footage. We find

\footnotetext{
${ }^{14}$ This is a very small impact which suggest that the estimated coefficient should be robust to using the traditional OLS model. Confirming to our intuition the OLS results were similar to the SARAR model results.
} 
that a one foot increase in the heated square foot is expected to increase the property price by \$29. Flood damages have an expected negative sign and are significant (at a 1 percent level).

As a robustness check, in Table 4 we report the SARAR estimates of the DD models for an alternative proxy for flood damages, flood depth. This variable also has a negative sign although it is not statistically significant at the conventional levels. However, the results for the variables of interest are virtually identical: a 34\% discount for floodplain properties (FP) in Model 1, 40\% discount for inundated properties (IND) in Model 2, and a 42\% discount for inundated floodplain properties (IN_FP) and 33\% discount for inundated and outside the floodplain properties (IN_OFP) in Model 3.

As an additional robustness check, we reestimated the models, this time with a nonlinear, logarithmic time trend (lnyear) (Table 5). As in Table 3, we do not find a significant discount for floodplain properties (FP) or inundated properties (IND) before the 1994 flood. Flood risks are capitalized into property prices only after the flood as indicated by the interactions of these two variables with the flood dummy. Compared to the linear decay specification, the estimates of Model 1 indicate a lower discount of floodplain properties immediately following the flood (but still sizeable at $21 \%$ ), ${ }^{15}$ and a slower decay, consistent with a logarithmic specification; the discount is not statistically different from zero nine years after the flood. The same pattern is observed when flood risk is defined in terms of being located in the inundated area (Model 2). As before, the non-inundated properties were not discounted significantly after the flood even if they were located in the floodplain (NIN_FP is not statistically significant in Model 3).

${ }^{15}$ Given by $(\exp (-0.23)-1) *(1 /(1-0.00547))$. 


\section{Conclusion}

Natural hazards provide exogenous risk information. Previous studies have found that the information provided by large floods is capitalized into property prices. These studies use floodplain maps to measure flood risk. Our study utilizes a flood inundation map in addition to the traditional FEMA floodplain map to determine the effect of the 1994 "flood of the century" caused by Tropical Storm Alberto in Albany, Georgia. This allows us to explore whether a potential effect of the flood was borne due to a pure information effect or an inundation effect.

The overall pattern of the findings suggests that there was a discount for floodplain properties only after the flooding, particularly in the floodplain properties that were inundated as well. Our results accord with Tversky and Kahneman’s “availability heuristic” (1973), which postulates judgments of probability to be reflective of the availability of information. When the impacts of floods are visualized and remembered, subjective risk probabilities are high, but as the effects of flooding fades over time (e.g. due to reconstruction), subjective probabilities decay and eventually vanish. In the absence of additional flooding, the price differential between the floodplain properties and the non-floodplain properties did indeed decay and vanish. However, there was no significant discount associated with properties in the floodplain if they were not in the inundated area. These results suggest that most of the discount in property prices in the area affected by a large flood event comes from being in the actually inundated area, and that not accounting for whether properties in the floodplains are also in the inundated area may overestimate the informational effect of large flood events and underestimate the value loss of inundated properties. The discount in inundated properties captures potential uninsurable reconstruction and psychological costs, and supports a hypothesis that homeowners respond better to what they have visualized ("seeing is believing”). 


\section{References:}

Anselin, L., and A.K. Bera. 1998. "Spatial dependence in linear regression models with an introduction to spatial econometrics." in A. Ullah and D. Giles, eds., Handbook of Applied Economic Statistics 155:237-290.

Anselin, L., and R. Florax. 1995. "Small sample properties of tests for spatial dependence in regression models: Some further results." New directions in spatial econometrics:21-74.

Arraiz, I., D.M. Drukker, H.H. Kelejian, and I.R. Prucha. 2010. "A Spatial Cliff-Ord Type Model with Heteroskedastic Innovations: Small and Large Sample Results." Journal of Regional Science 50(2):592-614.

Atreya, A., S. Ferreira, and W. Kriesel. 2013. "Forgetting the flood: Changes in Flood Risk Discount Over Time ."Land economics (forthcoming).

Bin, O., and C. Landry. 2012. "Changes in Implicit Flood Risk Premiums: Empirical Evidence from the Housing Market" forthcoming Journal of Environmental Economics \& management.

Bin, O., and S. Polasky. 2004. "Effects of flood hazards on property values: evidence before and after Hurricane Floyd." Land Economics 80(4):490.

Beatley, T., D. Brower, and A. Schwab. 2002. An Introduction to Coastal Zone Management, $2^{\text {nd }}$ ed. Island Press

Carbone, J., D. Hallstrom, and V. Smith. 2006. "Can natural experiments measure behavioral responses to environmental risks?" Environmental and Resource Economics 33(3):273297.

Chivers, J.and N.E. Flores.2002."Market Failure in Information: The national Flood Insurance Program" Land Economics 78: 515:521

Fingleton, B. 2008. "A generalized method of moments estimator for a spatial model with moving average errors, with application to real estate prices." Empirical Economics 34(1):35-57.

Fingleton, B., and J. Le Gallo. 2008. "Estimating spatial models with endogenous variables, a spatial lag and spatially dependent disturbances: Finite sample properties." Papers in Regional Science 87(3):319-339.

Freeman, A. 2003. The measurement of environmental and resource values: theory and methods: RFF press. 
Harrison, D.M., G. T. Smersh, and A.L. Schwartz. 2001. "Environmental determinants of housing prices: the impact of flood zone status." Journal of Real Estate Research 21(1):3-20.

MacDonald, D., J. Murdoch, and H. White. 1987. "Uncertain hazards, insurance, and consumer choice: Evidence from housing markets." Land Economics 63(4):361-371.

Kelejian, H.H., and I.R. Prucha. 2010. "Specification and estimation of spatial autoregressive models with autoregressive and heteroskedastic disturbances." Journal of Econometrics 157(1):53-67.

Kelejian, H. H. and I. R. Prucha. 1998. “A Generalized Spatial Two-Stage Least Squares procedure for Estimating a Spatial Autoregressive Model with Autoregressive Disturbances,” Journal of Real Estate Finance and Economics, 17(1), 99-121

Kim, C.W., T. T. Phipps, and L.Anselin. 2003. "Measuring the Benefits of air quality improvement: A spatial hedonic approach.” Journal of Environmental Economics and Management 45 (1):24-39

Kissling, W.D., and G. Carl. 2008. "Spatial autocorrelation and the selection of simultaneous autoregressive models." Global Ecology and Biogeography 17(1):59-71.

Kousky, C. 2010. "Learning from Extreme Events: Risk Perceptions after the Flood." Land Economics 86(3):395

Palmquist, R.B. 2005. "Property value models," in Handbook of Environmental Economics: Valuing Environmental Changes, volume 2, K.G. Mäler and J. Vincent, eds., Elsevier, Amsterdam.

Rosen, S. 1974. "Hedonic prices and implicit markets: product differentiation in pure competition." The Journal of Political Economy 82(1):34-55.

Shohan S. A., and S.P. Simonovic. 2013. "Spatial and temporal analysis of urban flood risk assessment”, Urban Water Journal, 10:1, 26-49

Simonovic, S.P., 2011. Systems approach to management of disasters: methods and applications. New York: John Wiley \& Sons.

Sjöberg, L. 2000. "Factors in risk perception." Risk analysis 20(1):1-12.

Shilling, J., J. Benjamin, and C. Sirmans. 1985. "Adjusting comparable sales for floodplain location." The Appraisal Journal 53(3):429-436.

Skantz, T., and T. Strickland. 1996. "House prices and a flood event: an empirical investigation of market efficiency." Journal of Real Estate Research 2(2):75-83.

Slovic, P., 2000. The perception of risk. London: Earthscan Publication Ltd 
Speyrer, J.F., and W.R. Ragas. 1991. "Housing prices and flood risk: an examination using spline regression." The Journal of Real Estate Finance and Economics 4(4):395-407.

Stamey, T.C. 1996. "Summary of data-collection activities and effects of flooding from Tropical Storm Alberto in parts of Georgia, Alabama, and Florida, July 1994."

Tversky, A., and D. Kahneman. 1973. "Availability: A heuristic for judging frequency and probability." Cognitive psychology 5(2):207-232

U.S. Census Bureau.2010. State and County Quick Facts:Dougherty County, Georgia, Retrieved February 20, 2012 from http://quickfacts.census.gov/qfd/states/13/13095.html

Zhai, G., T. Fukuzono, and S. Ikeda. 2003. "Effect of flooding on megalopolitan land prices: A case study of the 2000 Tokai flood in Japan." Journal of Natural Disaster Science 25(1):23-36. 
Table 1: Number of Properties in Different Flood Hazard Categories, Albany

\begin{tabular}{lc}
\hline Category & Number of Properties \\
\hline Inundated (IN) & 793 \\
Non-Inundated (NIN) & 1892 \\
& \\
Inside Floodplain (FP) & 615 \\
Outside Floodplain (OFP) & 2070 \\
& \\
Inundated and in floodplain (IN_FP) & 551 \\
Inundated but outside floodplain (IN_OFP) & 242 \\
Non-Inundated and in floodplain (NIN_FP) & 64 \\
Non Inundated outside floodplain (NIN_OFP) & 1828 \\
\hline
\end{tabular}


Table 2: Variables and Descriptive Statistics of "Flood Inundation Study Area”, Albany

\begin{tabular}{|c|c|c|c|c|c|}
\hline Variable & Description & Mean & Std. Dev. & Min & Max \\
\hline Price & Sale price of Property (2007 constant dollars) & 80221 & 153157 & 1854 & 1400000 \\
\hline Depth & Flood depth during 1994 Flood (feet) & 5.04 & 2.20 & 0.09 & 14.23 \\
\hline Avg_Dam & Average Damage by census block (thousand \$) & 0.37 & 2.32 & 0 & 27.5 \\
\hline Years & Number of years after 1994 Flood & 4.88 & 4.56 & 0 & 13 \\
\hline Elevation & Elevation of Property (meters) & 191.82 & 9.32 & 175 & 216 \\
\hline River & Distance to Nearest River (meters) & 671 & 466 & 6 & 2346 \\
\hline Lake & Distance to Nearest Lake (meters) & 727 & 351 & 10 & 1681 \\
\hline Railroad & Distance to Nearest Railroad (meters) & 1045 & 639 & 21 & 2750 \\
\hline Roads & Distance to Nearest Road (meters) & 30 & 23 & 0.02 & 154 \\
\hline Utilities & Distance to Nearest Utility Lines (meters) & 3462 & 1446 & 734 & 6268 \\
\hline Park & Distance to Nearest Park (meters) & 1771 & 737 & 47 & 3137 \\
\hline School & Distance to Nearest School (meters) & 854 & 435 & 44 & 2036 \\
\hline Year built & Year the Property was built & 1962 & 22 & 1883 & 2008 \\
\hline Acres & Total Acreage of the Property & 0.26 & 0.20 & 0 & 3.73 \\
\hline Bedrooms & Number of Bedrooms & 2.81 & 0.58 & 0 & 8 \\
\hline Fullbths & Number of Full baths & 1.31 & 0.51 & 1 & 7 \\
\hline Halfbths & Number of Half Baths & 0.10 & 0.30 & 0 & 2 \\
\hline Htdsqft & Heated Square Feet & 1195 & 427 & 480 & 4714 \\
\hline Fireplace & Number of Fireplaces & 0.14 & 0.35 & 0 & 1 \\
\hline $\mathrm{AC}$ & 1 if central AC present, else 0 & 0.67 & 0.47 & 0 & 1 \\
\hline Garage & 1 if garage present, else 0 & 0.03 & 0.16 & 0 & 1 \\
\hline Brick & 1 if Brick exterior, else 0 & 0.03 & 0.17 & 0 & 1 \\
\hline Flood & 1 if sold after July 1994, else 0 & 0.70 & 0.46 & 0 & 1 \\
\hline FP & 1 if in $100 y r$ Floodplain, else 0 & 0.23 & 0.42 & 0 & 1 \\
\hline IND & 1 if in inundated area during 1994 Flood, else 0 & 0.29 & 0.45 & 0 & 1 \\
\hline IN_FP & 1 if inundated in FP, else 0 & 0.21 & 0.40 & 0 & 1 \\
\hline IN_OFP & 1 if inundated outside FP, else 0 & 0.09 & 0.29 & 0 & 1 \\
\hline NIN_FP & 1 if non inundated in FP, else 0 & 0.02 & 0.15 & 0 & 1 \\
\hline NIN_OFP & 1 if non inundated outside FP, else 0 & 0.68 & 0.47 & 0 & 1 \\
\hline Income & Median household income by census block group & 20545 & 6110 & 6907 & 42964 \\
\hline PcBlk & Percent of non-whites by census block group & $85 \%$ & $20 \%$ & 15.8 & 100 \\
\hline
\end{tabular}


Table 3: SARAR Estimates of Difference-In-Difference (DD) Model with Linear Time Trend (Years)

\begin{tabular}{|c|c|c|c|}
\hline Variables & Model 1 & Model 2 & Model 3 \\
\hline FP & $\begin{array}{c}-0.0664 \\
(0.100)\end{array}$ & & \\
\hline FP*Flood & $\begin{array}{c}-0.395^{* * *} \\
(0.122)\end{array}$ & & \\
\hline FP*Years & $\begin{array}{c}0.0503^{* * * *} \\
(0.0126)\end{array}$ & & \\
\hline IND & & $\begin{array}{l}-0.0445 \\
(0.0889)\end{array}$ & \\
\hline IND*Flood & & $\begin{array}{c}-0.496^{* * * *} \\
(0.115)\end{array}$ & \\
\hline IND*Years & & $\begin{array}{c}0.0649 * * * \\
(0.0115)\end{array}$ & \\
\hline IN_FP & & & $\begin{array}{c}-0.0999 \\
(0.111)\end{array}$ \\
\hline IN_OFP & & & $\begin{array}{l}0.0164 \\
(0.138)\end{array}$ \\
\hline NIN_FP & & & $\begin{array}{l}0.0269 \\
(0.198)\end{array}$ \\
\hline Flood & $\begin{array}{c}0.149 \\
(0.196)\end{array}$ & $\begin{array}{c}0.188 \\
(0.196)\end{array}$ & $\begin{array}{c}0.183 \\
(0.196)\end{array}$ \\
\hline IN_FP*Flood & & & $\begin{array}{c}-0.526 * * * \\
(0.129)\end{array}$ \\
\hline IN_OFP*Flood & & & $\begin{array}{c}-0.397 * * \\
(0.200)\end{array}$ \\
\hline NIN_FP*Flood & & & $\begin{array}{c}0.387 \\
(0.354)\end{array}$ \\
\hline f(Years) & $\begin{array}{l}-0.000836 \\
(0.00838)\end{array}$ & $\begin{array}{l}-0.00842 \\
(0.00858)\end{array}$ & $\begin{array}{l}-0.00555 \\
(0.00868)\end{array}$ \\
\hline IN_FP*f(Years) & & & $\begin{array}{c}0.0709 * * * \\
(0.0134)\end{array}$ \\
\hline IN_OFP*f(Years) & & & $\begin{array}{c}0.0458 * * \\
(0.0179)\end{array}$ \\
\hline NIN_FP*f(Years) & & & $\begin{array}{l}-0.0604^{*} \\
(0.0342)\end{array}$ \\
\hline $\begin{array}{l}\text { Damage (= census block } \\
\text { average damage) }\end{array}$ & $\begin{array}{c}-0.0270 * * * \\
(0.00870)\end{array}$ & $\begin{array}{c}-0.0254 * * * \\
(0.00863)\end{array}$ & $\begin{array}{c}-0.0236 * * * \\
(0.00873)\end{array}$ \\
\hline Elevation & $\begin{array}{c}0.00358 \\
(0.00317)\end{array}$ & $\begin{array}{c}0.00412 \\
(0.00318)\end{array}$ & $\begin{array}{c}0.00333 \\
(0.00328)\end{array}$ \\
\hline Ln(River) & $\begin{array}{l}-0.0411 \\
(0.0567)\end{array}$ & $\begin{array}{l}-0.0204 \\
(0.0529)\end{array}$ & $\begin{array}{l}-0.0365 \\
(0.0568)\end{array}$ \\
\hline Ln(Lake) & $\begin{array}{c}0.0417 \\
(0.0513)\end{array}$ & $\begin{array}{c}0.0482 \\
(0.0509)\end{array}$ & $\begin{array}{c}0.0393 \\
(0.0522)\end{array}$ \\
\hline Ln(Railroad) & $\begin{array}{c}-0.186 * * * \\
(0.0300)\end{array}$ & $\begin{array}{c}-0.186 * * * \\
(0.0294)\end{array}$ & $\begin{array}{c}-0.183^{* * * *} \\
(0.0301)\end{array}$ \\
\hline Ln(Road) & $\begin{array}{l}-0.0200 \\
(0.0167)\end{array}$ & $\begin{array}{l}-0.0201 \\
(0.0167)\end{array}$ & $\begin{array}{l}-0.0197 \\
(0.0167)\end{array}$ \\
\hline Ln(Utility) & $\begin{array}{l}-0.0207 \\
(0.0608)\end{array}$ & $\begin{array}{l}-0.0348 \\
(0.0584)\end{array}$ & $\begin{array}{l}-0.0208 \\
(0.0621)\end{array}$ \\
\hline Ln(Park) & $\begin{array}{c}-0.237 * * * \\
(0.0555)\end{array}$ & $\begin{array}{c}-0.230 * * * \\
(0.0532)\end{array}$ & $\begin{array}{c}-0.242 * * * \\
(0.0560)\end{array}$ \\
\hline Ln(School) & $-0.0673 *$ & $-0.0692 *$ & $-0.0717 *$ \\
\hline
\end{tabular}




\begin{tabular}{|c|c|c|c|}
\hline & $(0.0382)$ & $(0.0382)$ & $(0.0383)$ \\
\hline \multirow[t]{2}{*}{ Acres } & 0.157 & 0.189 & 0.172 \\
\hline & (0.189) & (0.189) & $(0.190)$ \\
\hline \multirow[t]{2}{*}{ Acres $\wedge 2$} & 0.0176 & 0.00961 & 0.0140 \\
\hline & $(0.0667)$ & $(0.0667)$ & $(0.0667)$ \\
\hline \multirow[t]{2}{*}{ Age } & -0.00175 & -0.00199 & -0.00223 \\
\hline & $(0.00282)$ & $(0.00283)$ & $(0.00285)$ \\
\hline \multirow[t]{2}{*}{ Age^2 } & $-0.00010^{* * *}$ & $-9.88 \mathrm{e}-05^{* * *}$ & $-9.9 e-05^{* * *}$ \\
\hline & $(3.04 \mathrm{e}-05)$ & $(3.05 e-05)$ & $(3.07 e-05)$ \\
\hline \multirow[t]{2}{*}{ Bedroom } & -0.0226 & -0.0356 & -0.0317 \\
\hline & $(0.152)$ & $(0.152)$ & $(0.152)$ \\
\hline \multirow[t]{2}{*}{ Bedroom^2 } & 0.00115 & 0.00394 & 0.00348 \\
\hline & $(0.0260)$ & $(0.0260)$ & (0.0259) \\
\hline \multirow[t]{2}{*}{ Fullbath } & 0.0813 & 0.0925 & 0.0830 \\
\hline & $(0.128)$ & $(0.128)$ & $(0.128)$ \\
\hline \multirow[t]{2}{*}{ Fullbath^2 } & -0.0280 & -0.0310 & -0.0299 \\
\hline & $(0.0350)$ & $(0.0349)$ & (0.0349) \\
\hline \multirow[t]{2}{*}{ Halfbath } & -0.383 & -0.393 & -0.397 \\
\hline & $(0.460)$ & (0.459) & $(0.459)$ \\
\hline \multirow[t]{2}{*}{ Halfbath^2 } & 0.339 & 0.348 & 0.350 \\
\hline & $(0.446)$ & $(0.445)$ & $(0.444)$ \\
\hline \multirow[t]{2}{*}{ Heated sqft } & $0.000361 * *$ & $0.000344 * *$ & $0.00035 * *$ \\
\hline & (0.000173) & $(0.000173)$ & (0.000172) \\
\hline \multirow[t]{2}{*}{ Heated Sqft $\wedge 2$} & 2.17e-08 & 2.32e-08 & 2.29e-08 \\
\hline & $(4.64 \mathrm{e}-08)$ & $(4.63 e-08)$ & $(4.63 e-08)$ \\
\hline \multirow[t]{2}{*}{ Fireplace } & 0.0633 & 0.0693 & 0.0686 \\
\hline & $(0.0578)$ & $(0.0577)$ & $(0.0577)$ \\
\hline \multirow[t]{2}{*}{ Brick Ext. } & 0.0286 & 0.0352 & 0.0349 \\
\hline & $(0.117)$ & $(0.117)$ & $(0.117)$ \\
\hline \multirow[t]{2}{*}{$\mathrm{AC}$} & 0.00520 & 0.0104 & 0.0106 \\
\hline & $(0.0455)$ & $(0.0454)$ & $(0.0454)$ \\
\hline \multirow[t]{2}{*}{ Garage } & 0.0875 & 0.101 & 0.0964 \\
\hline & $(0.112)$ & $(0.111)$ & $(0.111)$ \\
\hline \multirow[t]{2}{*}{ Ln(Income) } & $0.530 * * *$ & $0.537 * * *$ & $0.540 * * *$ \\
\hline & $(0.122)$ & $(0.121)$ & $(0.123)$ \\
\hline \multirow[t]{2}{*}{$\%$ of Black } & -0.0270 & -0.0120 & -0.0222 \\
\hline & $(0.116)$ & $(0.116)$ & $(0.117)$ \\
\hline \multirow[t]{2}{*}{ Constant } & $8.745^{* * *}$ & $8.378 * * *$ & $8.713^{* * *}$ \\
\hline & (2.300) & $(2.310)$ & (2.342) \\
\hline \multirow[t]{2}{*}{ Lambda } & $0.00557 * * *$ & $0.00552 * * *$ & $0.0056 * * *$ \\
\hline & $(0.000890)$ & (0.000894) & (0.000894) \\
\hline \multirow[t]{2}{*}{ Rho } & $0.0585^{* * *}$ & $0.0591^{* * *}$ & $0.0590 * * *$ \\
\hline & $(0.00501)$ & $(0.00500)$ & $(0.00501)$ \\
\hline R-squared & 0.185 & 0.190 & 0.191 \\
\hline Observations & 2,685 & 2,685 & 2,685 \\
\hline
\end{tabular}


Table 4: SARAR Estimates of Difference-In-Difference (DD) Model with Linear Time Trend (Years) and alternative definition of damages

\begin{tabular}{|c|c|c|c|}
\hline Variables & Model 1 & Model 2 & Model 3 \\
\hline FP & $\begin{array}{c}-0.0624 \\
(0.104)\end{array}$ & & \\
\hline FP*Flood & $\begin{array}{c}-0.417^{* * * *} \\
(0.122)\end{array}$ & & \\
\hline FP*Years & $\begin{array}{c}0.0576 * * * \\
(0.0124)\end{array}$ & & \\
\hline IND & & $\begin{array}{l}0.0426 \\
(0.113)\end{array}$ & \\
\hline IND*Flood & & $\begin{array}{c}-0.512 * * * \\
(0.115)\end{array}$ & \\
\hline IND*Years & & $\begin{array}{c}0.0706 * * * \\
(0.0114)\end{array}$ & \\
\hline IN_FP & & & $\begin{array}{l}-0.0249 \\
(0.134)\end{array}$ \\
\hline IN_OFP & & & $\begin{array}{c}0.121 \\
(0.154)\end{array}$ \\
\hline NIN_FP & & & $\begin{array}{l}0.0223 \\
(0.198)\end{array}$ \\
\hline Flood & $\begin{array}{l}0.0847 \\
(0.195)\end{array}$ & $\begin{array}{c}0.132 \\
(0.195)\end{array}$ & $\begin{array}{c}0.133 \\
(0.195)\end{array}$ \\
\hline IN_FP*Flood & & & $\begin{array}{c}-0.547 * * * \\
(0.129)\end{array}$ \\
\hline IN_OFP*Flood & & & $\begin{array}{c}-0.401^{* *} \\
(0.200)\end{array}$ \\
\hline NIN_FP*Flood & & & $\begin{array}{c}0.388 \\
(0.355)\end{array}$ \\
\hline f(Years) & $\begin{array}{c}0.00413 \\
(0.00826)\end{array}$ & $\begin{array}{c}-0.00424 \\
(0.00847)\end{array}$ & $\begin{array}{c}-0.00159 \\
(0.00857)\end{array}$ \\
\hline IN_FP*f(Years) & & & $\begin{array}{c}0.0784^{* * *} * \\
(0.0131)\end{array}$ \\
\hline IN_OFP*f(Years) & & & $\begin{array}{c}0.0468 * * * \\
(0.0179)\end{array}$ \\
\hline NIN_FP*f(Years) & & & $\begin{array}{c}-0.0597^{*} \\
(0.0342)\end{array}$ \\
\hline Damage $=$ flood depth & $\begin{array}{c}-0.0188 \\
(0.0116)\end{array}$ & $\begin{array}{c}-0.0275^{*} \\
(0.0165)\end{array}$ & $\begin{array}{c}-0.0264 \\
(0.0166)\end{array}$ \\
\hline Lambda & $\begin{array}{c}0.00541 * * * \\
(0.000889)\end{array}$ & $\begin{array}{c}0.00541 * * * \\
(0.000892)\end{array}$ & $\begin{array}{c}0.00549 * * * \\
(0.000891)\end{array}$ \\
\hline Observations & $\begin{array}{c}0.0580 * * * \\
(0.00504) \\
0.186 \\
2,685\end{array}$ & $\begin{array}{c}0.0587 * * * \\
(0.00504) \\
0.191 \\
2,685 \\
\end{array}$ & $\begin{array}{c}0.0585 * * * \\
(0.00506) \\
0.192 \\
2,685\end{array}$ \\
\hline
\end{tabular}

Notes: Robust Standard errors in parentheses; *** $\mathrm{p}<0.01,{ }^{* *} \mathrm{p}<0.05,{ }^{*} \mathrm{p}<0.1$; all the structural attributes, location attributes, and year fixed effects are included in the model (their estimated coefficients are available upon request). 


\section{Table 5: SARAR Estimates of Difference-In-Difference (DD) Models for Flood Risk using}

Logarithmic Time Trend (InYears).

\begin{tabular}{|c|c|c|c|}
\hline VARIABLES & Model 1 & Model 2 & Model 3 \\
\hline FP & $\begin{array}{c}-0.128 \\
(0.103)\end{array}$ & & \\
\hline FP*Flood & $\begin{array}{c}-0.230 * * \\
(0.108)\end{array}$ & & \\
\hline FP*Years & $\begin{array}{c}0.156 * * * \\
(0.0508)\end{array}$ & & \\
\hline IND & & $\begin{array}{c}-0.0988 \\
(0.0921)\end{array}$ & \\
\hline IND*Flood & & $\begin{array}{c}-0.202 * * \\
(0.101)\end{array}$ & \\
\hline IND*Years & & $\begin{array}{c}0.140 * * * \\
(0.0466)\end{array}$ & \\
\hline IN_FP & & & $\begin{array}{c}-0.161 \\
(0.114)\end{array}$ \\
\hline IN_OFP & & & $\begin{array}{l}-0.0220 \\
(0.145)\end{array}$ \\
\hline NIN_FP & & & $\begin{array}{l}-0.0205 \\
(0.204)\end{array}$ \\
\hline Flood & $\begin{array}{c}0.131 \\
(0.201)\end{array}$ & $\begin{array}{c}0.136 \\
(0.199)\end{array}$ & $\begin{array}{l}0.0298 \\
(0.199)\end{array}$ \\
\hline IN_FP*Flood & & & $\begin{array}{c}-0.240 * * \\
(0.114)\end{array}$ \\
\hline IN_OFP*Flood & & & $\begin{array}{l}-0.130 \\
(0.174)\end{array}$ \\
\hline NIN_FP*Flood & & & $\begin{array}{l}-0.198 \\
(0.314)\end{array}$ \\
\hline f(Years) & $\begin{array}{c}-0.0821 * * * \\
(0.0239)\end{array}$ & $\begin{array}{c}-0.0853 * * * \\
(0.0245)\end{array}$ & $\begin{array}{c}-0.0878 * * * \\
(0.0248)\end{array}$ \\
\hline IN_FP*f(years) & & & $\begin{array}{c}0.170 * * * \\
(0.0536)\end{array}$ \\
\hline IN_OFP*f(years) & & & $\begin{array}{c}0.0710 \\
(0.0766)\end{array}$ \\
\hline NIN_FP*f(years) & & & $\begin{array}{l}0.0930 \\
(0.145)\end{array}$ \\
\hline $\begin{array}{l}\text { Damage (= census block } \\
\text { average damage) }\end{array}$ & $\begin{array}{c}-0.0312 * * * \\
(0.00859)\end{array}$ & $\begin{array}{c}-0.0320 * * * \\
(0.00856)\end{array}$ & $\begin{array}{c}-0.0306 * * * \\
(0.00863)\end{array}$ \\
\hline Lambda & $\begin{array}{c}0.00547 * * * \\
(0.000894)\end{array}$ & $\begin{array}{c}0.00549 * * * \\
(0.000895)\end{array}$ & $\begin{array}{c}0.00551 * * * \\
(0.000897)\end{array}$ \\
\hline Rho & $\begin{array}{c}0.0590 * * * \\
(0.00509)\end{array}$ & $\begin{array}{c}0.0589 * * * \\
(0.00509)\end{array}$ & $\begin{array}{c}0.0589 * * * \\
(0.00510)\end{array}$ \\
\hline R-Squared & 0.190 & 0.186 & 0.191 \\
\hline Observations & 2,685 & 2,685 & 2,685 \\
\hline
\end{tabular}



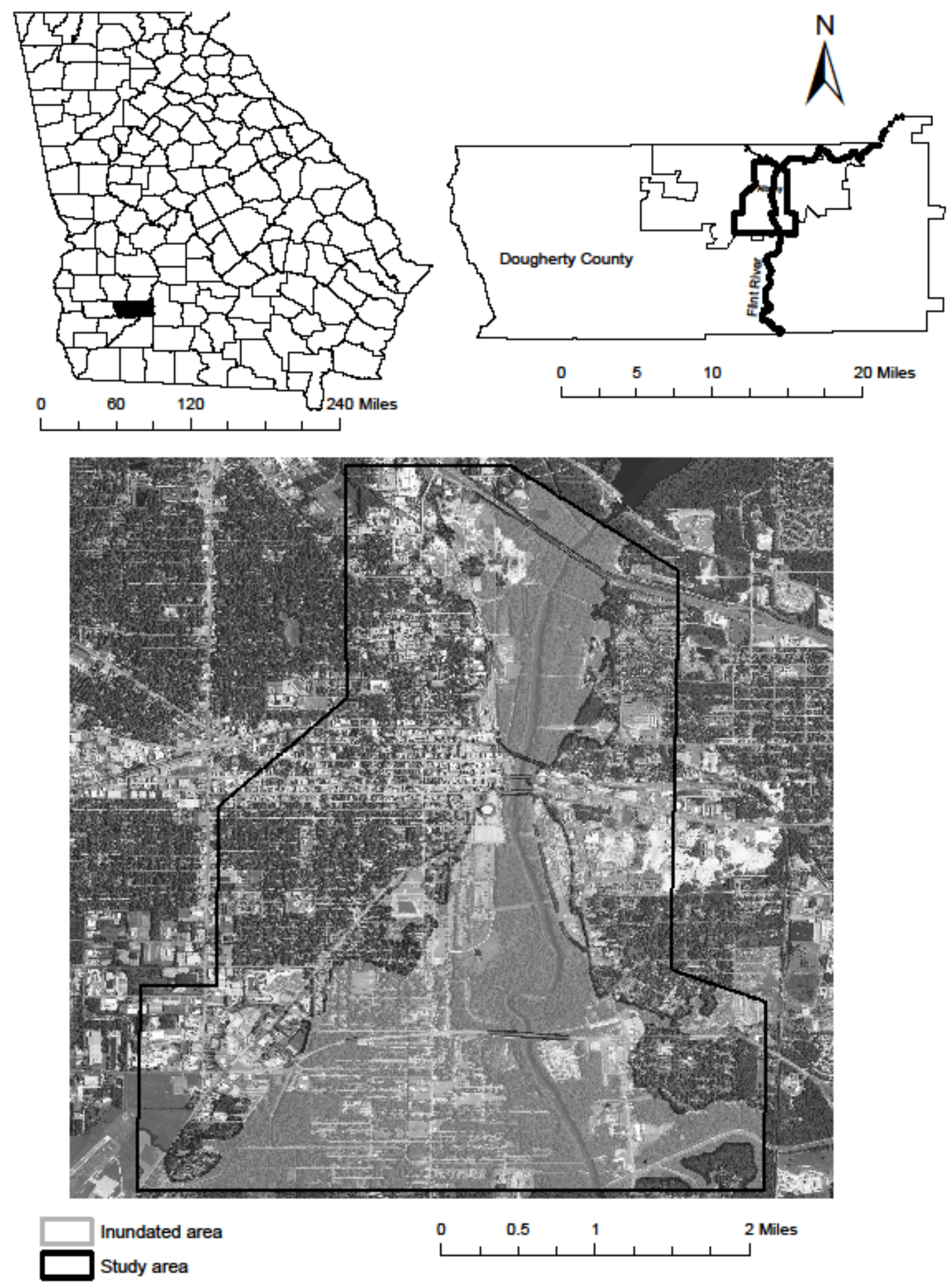

Figure 1. Flood Inundation Study Area: Albany, Georgia 